\title{
A Chastened Communion: Modern Irish Poetry and Catholicism
}

\section{Eamon Maher}

\section{(2) OpenEdition \\ 1 Journals}

\section{Édition électronique}

URL : http://journals.openedition.org/etudesirlandaises/4746

DOI : 10.4000/etudesirlandaises.4746

ISSN : 2259-8863

\section{Éditeur}

Presses universitaires de Caen

\section{Édition imprimée}

Date de publication : 15 décembre 2015

Pagination : 155-157

ISBN : 978-2-7535-4366-9

ISSN : 0183-973X

\section{Référence électronique}

Eamon Maher, "A Chastened Communion: Modern Irish Poetry and Catholicism », Études irlandaises [En ligne], 40-2 | 2015, mis en ligne le 15 décembre 2015, consulté le 24 septembre 2020. URL : http:// journals.openedition.org/etudesirlandaises/4746; DOI : https://doi.org/10.4000/etudesirlandaises. 4746

\section{(c) (1) ()}

Études irlandaises est mise à disposition selon les termes de la Licence Creative Commons Attribution - Pas d'Utilisation Commerciale - Partage dans les Mêmes Conditions 4.0 International. 


\title{
Comptes rendus de lecture
}

\author{
Book Reviews
}

Andy Auge, A Chastened Communion: Modern Irish Poetry and Catholicism, New York, Syracuse University Press, 2013, 288 p. ISBN 9780815633297.

In this most welcome and insightful book of essays, Andy Auge sets about analysing the role of Catholicism in the work of 7 modern Irish poets: Austin Clarke, Patrick Kavanagh, John Montague, Seamus Heaney, Eiléan Ní Chuilleanáin, Paul Durcan and Paula Meehan. Clearly, you have in this choice a mixture of highly decorated figures, one a Nobel Laureate, and some less well-established voices, although all extremely well-established among the reading public. The overall impression given as one reads through the chapters is that the author has a genuine feeling for the Catholic sensibility of the writers which leads them to incorporate rituals, beliefs and practices from their religious background into their work. What is admirable also is the way in which each poet is situated in relation to the socio-religious context in which he/she wrote. Most would be what we describe as "lapsed Catholics" but, as is so often the case, the memories from the past nurtured their art and Catholicism was the language of their youth, something that could not be dispensed with lightly.

The Introduction sets out its stall in a clear manner, discussing the way in which Ireland has moved from being a very religious country to one where Catholicism is now "an increasingly endangered species". The clerical abuse scandals have left their mark, as have the various Reports that emerged in their wake. 2009 is cited as the year when both the Ryan and the Murphy Reports were published, with disastrous consequences for the reputation of the Catholic Church. The Cloyne Report in 2011 added more fuel to an already overheated fire and it prompted an unprecedented attack in Dáil Éireann by An Taoiseach Enda Kenny, who accused the Vatican of frustrating "an inquiry in a sovereign, democratic republic". Coming as this did from a practicing Catholic and the leader of a centre-right party traditionally considered close to the Catholic Church, made Kenny's intervention all the more remarkable and highlighted the hugely changed religious landscape in Ireland. 
The poets dealt with in this study drew "imaginative sustenance" from the Catholic atmosphere in which they grew up, as Auge so correctly states:

However divergent their poetic styles may be, a common pattern persists: a demythologizing critique of some elemental feature of Irish Catholicism - the sacraments of confession and the Eucharist, the pilgrimages to holy wells and Lough Derg, the worshipping of relics and adoration of the Blessed Virgin, the imperative to self-sacrifice, the narrowly patriarchal nature of the institution elicits, in turn, a radical reshaping of these traditional religious phenomena (3).

This analysis reveals a commentator who is well-attuned to his subject and who is capable of expressing his views in a clear, accessible and insightful manner. Reference is made to the way Joyce abandoned Catholicism to adopt the religion of art and yet continued to make use of his religious training in his work - quotes from Augustine abound in Joyce and his anti-clericalism was often more of a mask than a sincerely held belief. His real target was not so much the Catholic Church as the paralysis that it helped to induce in Irish people. Beckett's comment about poetry being analogous to prayer is quoted and the author rightly points out how Catholicism formed part of the dominant culture of the poets and entered their artistic mindset almost by osmosis. So, this is a balanced and wellargued Introduction that sets the tone for what is to follow.

The individual chapters are very well researched and thought through. They begin by situating the poet and his/her background and influences. Often a theorist is invoked to enforce some point about the work. For example, Foucault is used to analyse Clarke and to a lesser extent Kavanagh, Jean-Luc Marion for Montague, Nietzsche and Derrida for Heaney, Levinas for Ní Chuilleanáin, Bakhtin for Durcan, and so on. This works well in general, but one does have the impression at times that the theory is leading the analysis a bit too obviously. This is not meant to indicate that Auge is anything other than a skilled practitioner with a great understanding of both theory and text: it is just that there are places where the discussion becomes somewhat dense and impenetrable to this reader.

One major challenge for the collection that is also not completely overcome is to segue the various poets and the period during which they wrote. It is important that one chapter move seamlessly into the next and allow the reader to feel that $s /$ he is not reading a book of essays that have little or nothing to do with each other. This is probably easier said than done, however, and the theme does provide an overarching narrative that is developed throughout. Nevertheless, there are still places where more cross-referencing of the poets and their approach could yield rich dividends and show differences as well as similarities in their approach. For example, the period separating Clarke and Meehan was seismic, and the Ireland in which both poets were brought up would have been completely different in terms of religious practice and socio-economic climate. Hence it would have been 
worthwhile to chart this development and the impact it wrought on the poetry of both writers.

But this is probably a moot point when one considers the imposing scholarship and classic insights that are contained in Auge's commentary. This work is clearly the fruit of long reflection and study. The reading of the main texts by the poets is supplemented by a keen knowledge of the critical material available on them and the biographical and technical details that are so necessary to understand how they perfected their art. The chapters that caught my eye in particular were the ones on Heaney and Paul Durcan - the latter's treatment of priests was a real discovery and convinces me of just how steeped Durcan is in Catholic culture and how fascinated he was with clerical stereotypes, many of whom he turns into figures of fun. With Heaney, it was a more visceral attachment, as can be seen from the following extract quoted in the Introduction.

Far from being deprived of religion in my youth, I was oversupplied. I lived with, and to some extent lived by, divine mysteries: the sacrifice of the Mass, the transubstantiation of bread and wine into the body and blood of Christ, the forgiveness of sin, the resurrection of the body and the life of the world to come, the whole disposition of the cosmos from celestial to infernal, the whole supernatural population, the taxonomy of virtues and vices and so on (2).

Reading these lines, one is reminded of just how precious a reference Heaney was when it came to charting religious sensibility in Ireland. His poetry flowed out of his native Derry, the rituals of the farm, his parents' simple faith, the commitment to doing the small things well and leaving the big things to God. Auge has an excellent feel for Heaney and for all the other poets he deals with in the essays. Time does not unfortunately allow a more indepth discussion of the individual chapters of this fine book. I will conclude simply by saying that anyone with even a passing interest in modern Irish poetry and its links to Catholicism will find in Auge's book much satisfaction, information and enjoyment. The Catholic angle is shown to be an essential component of what the poets strive to achieve. A Chastened Communion is the first study of its kind and it will be the template on which further scholars who come to explore this fascinating area would do well to follow and attempt to emulate. Syracuse deserve great credit for the extremely high production quality of the book, which does credit to the fine traditions of this Press.

Eamon MAHER

National Centre for Franco-Irish Studies, IT Tallaght, Dublin 